\title{
Caveolin-1 is critical in the proliferative effect of leptin on osteoblasts through the activation of Akt
}

\author{
LIN ZOU, GUICHUN ZHANG, LIFENG LIU, CHEN CHEN, XUECHENG CAO and JINFANG CAI \\ Department of Traumatic Orthopedic Surgery, The General Hospital of Jinan Military Command, \\ Jinan, Shandong 250031, P.R. China
}

Received July 18, 2015; Accepted May 24, 2016

DOI: $10.3892 / \mathrm{mmr} .2016 .5461$

\begin{abstract}
Osteoblasts are critical in bone remodeling and the repair of bone fractures. Leptin is involved in bone metabolism and osteoblast survival through the downstream signaling pathway, however, the exact mechanism of the effect of leptin on osteoblasts remains to be fully elucidated. In the present study, hFOB 1.19 cells were used to observe the effects of leptin on cell proliferation and apoptosis, and to investigate the underlying mechanism. The results confirmed that treatment of hFOB 1.19 cells with leptin significantly induced cell proliferation. Western blot analysis showed that the expression of caveolin-1 and the activation of Akt in the cells treated with leptin were significantly increased, compared with the control cells. Additionally, inhibiting Akt activation eliminated the effects on cell proliferation induced by leptin. The rates of cell apoptosis and cell cycle distribution were examined using flow cytometry, which revealed a decrease in the apoptotic rate and an increase in the proportion of cells in the $\mathrm{S}$ phase. This indicated that leptin was capable of inducing cell proliferation by inhibiting apoptosis and stimulating cell progression to the $\mathrm{S}$ phase. Transfection of the cells with caveolin-1 small interfering RNA showed that the activation of Akt induced by leptin was significantly inhibited. Furthermore, caveolin-1 knockdown and inhibiting Akt activation eliminated the increased proliferation, increased proportion of cells in the $\mathrm{S}$ phase and increased anti-apoptotic effects induced by leptin. Taken together, the data obtained in the present study demonstrated that caveolin-1 was critical in the proliferative effect of leptin on osteoblasts via the activation of Akt.
\end{abstract}

Correspondence to: Professor Lin Zou, Department of Traumatic Orthopedic Surgery, The General Hospital of Jinan Military Command, 25 Shifan Street, Jinan, Shandong 250031, P.R. China E-mail:drzoulin@aliyun.com

Key words: leptin, caveiolin-1, phosphorylated-Akt, proliferation, osteoblast, Akt

\section{Introduction}

Leptin, an adipocytokine, is a $16-\mathrm{kD}$ a plasma protein primarily secreted by adipocytes $(1,2)$. It is also produced by oesteoblasts, placental syncytiotrophoblasts and gastric epithelium (3-6). A previous study demonstrated that leptin contributes to body weight homeostasis as a signal to affect food intake and energy expenditure (7). In addition to its physiological actions on lipid metabolism, angiogenesis, fertility and hematopoiesis, leptin has a pathological role in certain bone diseases, including osteoporosis, osteoarthritis, rheumatic arthritis, bone tumors and fractures (8-11).

It is well known that leptin is an important regulator of bone metabolism through peripheral and central signaling pathways. It has been suggested that the peripheral pathway is direct and involved in a stimulatory effect on bone formation, whereas the central pathway is indirect and exerts an inhibitory effect on bone growth, which is supported by observations of bone loss resulting from the intracerebrovesicular administration of leptin (12). By contrast, a previous study showed that the intracerebrovesicular injection of leptin enhances bone formation (13). Osteoblasts are major cells in the bone, and are responsible for mineralization during bone formation and later bone remodeling. As such, osteoblasts are critical in normal skeletal physiology and are involved in several pathological conditions, including osteoporosis, osteopetrosis and bone cancer (14). It has been shown that leptin can affect bone formation by mediating the activity of osteoblasts (15). However, the mechanisms underlying the effect of leptin on osteoblasts remain to be fully elucidated.

Caveolin-1 is an essential and signature protein of caveolae, and is found to be expressed at high levels in osteoblasts and endothelial cells (16). The removal of caveolin-1 has been demonstrated to prevent the formation of caveolae in these cells (16). Numerous studies have shown the importance of caveolae in vesicular trafficking, cell adhesion, apoptosis and senescence $(17,18)$. Although the predominant focus of interest has been centered on the role of caveolin-1 in cancer, there is substantial data providing evidence that it is also involved in bone metabolism $(19,20)$. It has also been demonstrated that caveolin-1 appears to be a key regulator of osteoblast differentiation and function, including mineralization and matrix protein deposition (16).

In the present study, it was confirmed that leptin promoted the proliferation of osteoblasts in vitro, and demonstrated for 
the first time, to the best of our knowledge, that caveolin-1 critically contributed to the proliferative effect of leptin on osteoblasts, and this was mediated by the activation of Akt The results may aid in the development of therapeutics for leptin-induced bone diseases.

\section{Materials and methods}

Cell culture and reagents. An osteoblastic cell line derived from the bone of human fetal osteoblasts (hFOB 1.19), was purchased from American Type Culture Collection (Manassas, VA, USA). In culture conditions of $37^{\circ} \mathrm{C}$ with $5 \% \mathrm{CO}_{2}$, the cells were grown in Dulbecco's modified Eagle's medium (DMEM; Sigma-Aldrich, St. Louis, MO, USA) at $\mathrm{pH} 7.4$, supplemented with $3.7 \mathrm{~g} / 1 \mathrm{NaHCO}_{3}, 4.77 \mathrm{~g} / 1 \mathrm{HEPES}, 10 \%$ fetal bovine serum (FBS; Invitrogen; Thermo Fisher Scientific, Waltham, MA, USA) and $0.5 \%$ penicillin/streptomycin $(50 \mathrm{U} / \mathrm{ml}$ penicillin and $50 \mu \mathrm{g} / \mathrm{ml}$ streptomycin; Sigma-Aldrich). Every 2-3 days, the medium was replaced. When the cell culture reached $\sim 85 \%$ confluence, subculture was performed. Cells at the third or fourth passage were used in the subsequent experiments.

Cell proliferation assay. Using an MTT assay, cell viability was evaluated. The cells were seeded in 96-well plates at a density of $3 \times 10^{3}$ cells per well. Following incubation overnight, the cells were exposed to leptin (Sigma-Aldrich); for 24-96 h Following incubation overnight, the cells were exposed to different concentration of leptin $(0,0.01,0.05,0.1,0.5,1,5$ and $10 \mu \mathrm{g} / \mathrm{ml}$ ) for $24 \mathrm{~h}$ or the cells were exposed to $0.5 \mu \mathrm{g} / \mathrm{ml}$ leptin for 24-96 h. Fresh complete medium (0.2 ml) supplemented with $20 \mu \mathrm{l}$ MTT dye $[(5 \mathrm{mg} / \mathrm{ml}$ in phosphate-buffered saline (PBS)] was added to each well. Following incubation at $37^{\circ} \mathrm{C}$ for $4 \mathrm{~h}$, each well was washed thoroughly with PBS. Subsequently, dimethyl sulfoxide (Sigma-Aldrich) was added to each well to terminate the MTT reaction and dissolve the formazan crystals. Following agitation at room temperature for $\sim 10 \mathrm{~min}$, the optical density (OD) of each well was measured at $450 \mathrm{~nm}$. The viability of the control cells were considered as $100 \%$, and the results were calculated as follows: $\left(\mathrm{OD}_{\text {treated cells }}-\mathrm{OD}_{\text {control cells }}\right) /\left(\mathrm{OD}_{\text {control cells }}-\mathrm{OD}_{\text {blank }}\right) \times 100 \%$.

Analysis of cell apoptosis. In 6-well plates, $2 \times 10^{5}$ cells/well were seeded and cultured overnight. Following treatment with $0.5 \mu \mathrm{g} / \mathrm{ml}$ leptin for $24 \mathrm{~h}$, the cells were trypsinized and washed with PBS. The cells were suspended in $0.3 \mathrm{ml}$ binding buffer, following by the addition of $2 \mu \mathrm{l}$ Annexin V (Beyotime Institute of Biotechnology, Haimen, China) and careful pipetting of the mixture. Following the addition of $5 \mu \mathrm{l}$ propidium iodide (PI; Beyotime Institute of Biotechnology), the mixture was incubated for $\sim 10 \mathrm{~min}$ at room temperature. The rates of apoptosis were detected using a FACSCSalibur flow cytometer (Becton-Dickinson; BD Biosciences, San Diego, CA, USA).

Cell cycle analysis. In 6 -well plates, $2 \times 10^{5}$ cells were seeded per well. Following $12 \mathrm{~h}$ starvation, the cells were treated with $0.5 \mu \mathrm{g} / \mathrm{ml}$ leptin for $24 \mathrm{~h}$ for $48 \mathrm{~h}$. Following trypsinization and washing with PBS, the cells were resuspended with $500 \mu \mathrm{l}$ medium containing $1 \mathrm{mg} / \mathrm{ml}$ RNase A and $100 \mu \mathrm{g} / \mathrm{ml}$ PI (Beyotime Institute of Biotechnology). Following incubation for $20 \mathrm{~min}$ at room temperature, in the dark, the DNA contents of the cells were measured using a FACSCalibur flow cytometer (Becton-Dickinson; BD Biosciences).

Small interfering (si)RNA knockdown. siRNA was used to knock down the gene expression of caveolin-1. A total of $5 \times 10^{4}$ cells/well were seeded in 24 -well tissue culture plates. Following incubation for $24 \mathrm{~h}$ at $37^{\circ} \mathrm{C}$, the medium was replaced. Using $6 \mu \mathrm{l}$ transfection reagent (Qiagen), transfections were performed using siRNA (Santa Cruz Biotechnology, Inc., Dallas, TX, USA) at a final concentration of $30 \mathrm{nM}$. Based on the half-life of $5 \mathrm{~h}$ for caveolin-1 protein (21), the cells in the wells were exposed to the transfection mixture for $24 \mathrm{~h}$ at $37^{\circ} \mathrm{C}$ prior to cell harvest.

Reverse transcription-quantitative polymerase chain reaction (RT-qPCR). Using TRIzol reagent (Takara Bio, Inc., Otsu, Japan), total RNA was extracted from the cells. A 200 ng quantity of total RNA was used to synthesize cDNA using M-MLV Reverse Transcriptase (Promega Corporation, Madison, WI, USA). Based on the previously published primers (22), qPCR was performed to measure the mRNA levels of caveolin-1. The primers were as follows: caveolin-1, forward 5'-TCA ACC GCG ACC CTA AAC ACC-3' and reverse 5-'TGA AAT AGC TCA GAA GAG ACA T-3'; $\beta$-actin, forward 5'-GGA GCA ATG ATC TTG ATC TT-3' and reverse 5'-CCT TCC TGG GCA TGG AGT CCT-3'. The conditions for qPCR were as follows: Enzyme activation at $95^{\circ} \mathrm{C}$ for $10 \mathrm{~min}, 40$ cycles of amplification and each of them consisted of denaturation at $95^{\circ} \mathrm{C}$ for $15 \mathrm{sec}$, annealing at $60^{\circ} \mathrm{C}$ for $60 \mathrm{sec}$, and extension at $60^{\circ} \mathrm{C}$ for $60 \mathrm{sec}$. The results were calculated with the comparative quantification cycle $(\mathrm{Cq})$ method. RT-qPCR was performed using the Applied Biosystems 7500 Sequence Detection system (Thermo Fisher Scientific, Inc.). The expression of caveolin-1 was normalized to $\beta$-actin. The conditions for qPCR were as follows: Enzyme activation at $95^{\circ} \mathrm{C}$ for $10 \mathrm{~min}$, followed by 40 cycles of amplification, each consisting of denaturation at $95^{\circ} \mathrm{C}$ for $15 \mathrm{sec}$, annealing at $60^{\circ} \mathrm{C}$ for $60 \mathrm{sec}$ and extension at $60^{\circ} \mathrm{C}$ for $60 \mathrm{sec}$. The results were calculated using the quantification cycle (Cq) method (23), and the expression of caveolin-1 was normalzed with $\beta$-actin.

Western blot analysis. Using lysis buffer (Beyotime Institute of Biotechnology), the cell lysates were prepared immediately following treatment. Protein concentrations were measured using the Bradford method (Bio-Rad Laboratories, Inc., Hercules, CA, USA). Equal quantities $(100 \mu \mathrm{g})$ of proteins were loaded and separated on $8 \%$ SDS-polyacrylamide gels. The proteins were then transferred onto PVDF membranes (EMD Millipore, Bedford, MA, USA). Following blocking in TBST buffer containing 5\% skim milk at room temperature for $2 \mathrm{~h}$, the blots were incubated at $4^{\circ} \mathrm{C}$ overnight with the following primary antibodies: Rabbit anti-calveolin-1 (cat. no. 3267), rabbit anti-p473-Akt (cat. no. 4060), rabbit anti-GAPDH (cat. no. 5174) and rabbit anti-Akt (cat. no. 4691) (Cell Signaling Technology, Inc. Danvers, MA, USA). The blots were then washed in TBST and incubated with the horseradish peroxidase-conjugated Chicken anti-rabbit IgG secondary antibodies (cat. no. sc-516087; Santa Cruz Biotechnology, Inc.) at room temperature for $1 \mathrm{~h}$. Following washing in TBST, the immunoreactive bands were visualized by enhancement using 
a chemiluminescence kit (Pierce Biotechnology, Rockford, IL, USA). The immunoreactive bands of GAPDH were used as an internal control.

Statistical analysis. Experiments were performed three times. Data are presented as the mean \pm standard deviation. Statistical differences were analyzed using the Student's two-sided $t$-test or one way analysis of variance using SPSS 21.0 software (IBM SPSS, Armonk, NY, USA). P $\leq 0.05$ was considered to indicate a statistically significant difference.

\section{Results}

Leptin promotes cell proliferation. To determine the effect of leptin on the growth of hFOB 1.19 cells, an MTT assay was performed. The cells were exposed to leptin at the doses of $0,0.01,0.05,0.1,0.5,1,5$ and $10 \mu \mathrm{g} / \mathrm{ml}$ for $24 \mathrm{~h}$. As shown in Fig. 1A, the cell viabilities at the doses ranging between 0.01 and $1 \mu \mathrm{g} / \mathrm{ml}$ were comparable with the control, whereas the cell viabilities at 5 and $10 \mu \mathrm{g} / \mathrm{ml}$ were marginally decreased, but not significantly, compared with that of the control.

Subsequently, time-response assessment was performed (Fig. 1B). The cells were incubated with $0.5 \mu \mathrm{g} / \mathrm{ml}$ leptin for 24, 48, 72 and 96 h. Between 24 and 72 h, a time-dependent increase in cell viability induced by leptin was observed. Although 96-h treatment with $0.5 \mu \mathrm{g} / \mathrm{ml}$ leptin resulted in a cell viability comparable with that of 72-h treatment, the cell viability was significantly increased, compared with that in the control group at $96 \mathrm{~h}$. Taken together, these findings indicated that leptin induced hFOB 1.19 cell proliferation.

Leptin induces the expression of caveolin-1. To observe the effect of lepin on the expression of caveolin-1, the cells were exposed to leptin at the gradient doses of $0,0.01$, $0.05,0.1,0.5,1,5$ and $10 \mu \mathrm{g} / \mathrm{ml}$ for $24 \mathrm{~h}$. The mRNA and protein expression levels of caveolin-1 showed a significant dose-dependent increase between doses of 0.05 and $5 \mu \mathrm{g} / \mathrm{ml}$, whereas $0.01 \mu \mathrm{g} / \mathrm{ml}$ leptin had no effect on the expression levels (Fig. 2A and B). Unexpectedly, the expression of caveolin-1 at $10 \mu \mathrm{g} / \mathrm{ml}$ was comparable to that at $5 \mu \mathrm{g} / \mathrm{ml}$. Subsequently, time-response assessment of the effect of leptin on the expression of caveolin-1 was performed. The cells were incubated with $0.5 \mu \mathrm{g} / \mathrm{ml}$ leptin for $12,24,36$ and $48 \mathrm{~h}$. A time-dependent increase in the expression of caveolin-1 was observed between 12 and $36 \mathrm{~h}$, whereas no increase in the expression of caveolin-1 was observed at $48 \mathrm{~h}$, compared with that at $36 \mathrm{~h}$ (Fig. 2C and D). Taken together, these results indicated that leptin induced the expression of caveolin-1.

Caveolin-1 konckdown decreases leptin-induced Akt activation. It has been reported that leptin can activate the phosphoinositide 3-kinase (PI3K) signaling pathway in a variety of cells, including vascular smooth muscle, nucleus pulposus and leukemic cells (24-26). Therefore, the present study evaluated the effect of caveolin-1 knockdown on the activation of the signaling pathway by leptin. As Akt is the immediate downstream kinase activated by PI3K, the level of p-Akt was measured in the present study. As shown in Fig. 3, the level of p-Akt was markedly increased in the hFOB 1.19 cells exposed to $0.5 \mu \mathrm{g} / \mathrm{ml}$
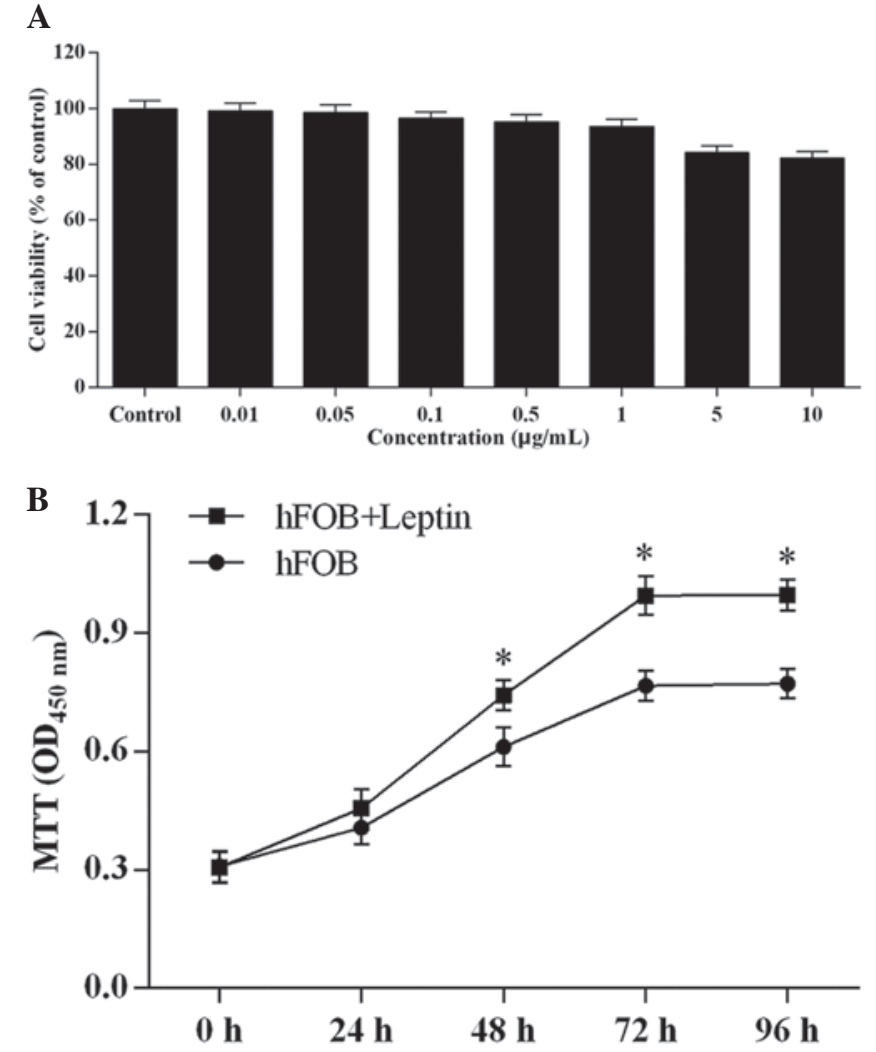

Figure 1. Leptin promotes the proliferation of hFOB 1.19 cells. The effect of leptin on cell viability was determined using an MTT assay. (A) Cell viabilities of hFOB 1.19 cells treated with a gradient of doses of leptin for $24 \mathrm{~h}$ and (B) treated with $0.5 \mu \mathrm{g} / \mathrm{ml}$ leptin for $24,48,72$ and $96 \mathrm{~h}$. ${ }^{*} \mathrm{P} \leq 0.05$ compared with the hFOB group at the same time point. Data are presented as the mean \pm standard deviation. OD, optical density.

leptin, whereas no significant change in the level of Akt was noted. Furthermore, the present study evaluated the effect of caveolin-1 on the activation of Akt by leptin. Caveolin-1 was knocked down by siRNA, and a marked decrease in the level of p-Akt was noted, indicating that caveolin-1 may functionally contribute to leptin-induced Akt activation. Additionally, the effect of Akt activation on the expression of caveolin-1 was evaluated. Following exposure to Akt inhibitor IV, the increased expression of caveolin-1 was significantly inhibited (Fig. 3).

Effect of caveolin-1 and p-Akt on leptin-induced cell proliferation. To evaluate the involvement of caveolin-1 and p-Akt in leptin-induced cell proliferation, the present study examined the effects of caveolin-1 knockdown and the inhibition of Akt activation on $0.5 \mu \mathrm{g} / \mathrm{ml}$ leptin-induced cell proliferation at 24, 48, 72 and $96 \mathrm{~h}$. As shown in Fig. 4, leptin treatment significantly increased cell viability, compared with the control group. As expected, the cell viabilities in the groups of cells with caveolin-1 knockdown and Akt inhibition were significantly suppressed, compared with leptin-treated group. Taken together, these results indicated that caeolin-1 knockdown and Akt inhibition individually counteracted the proliferative function of leptin.

Effect of caveolin-1 knockdown and Akt activation inhibition on the cell cycle distribution of cells exposed to leptin. The cell cycle distribution of the hFOB 1.19 cells was examined 
A

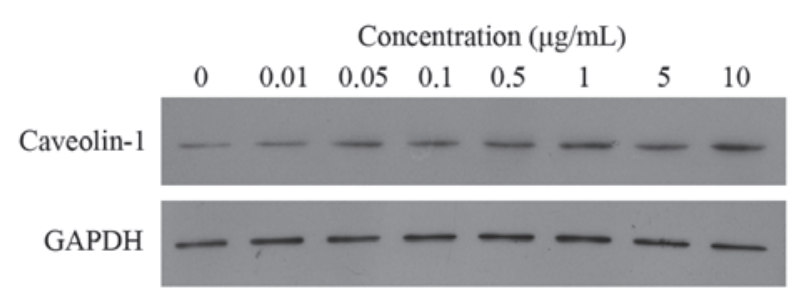

C

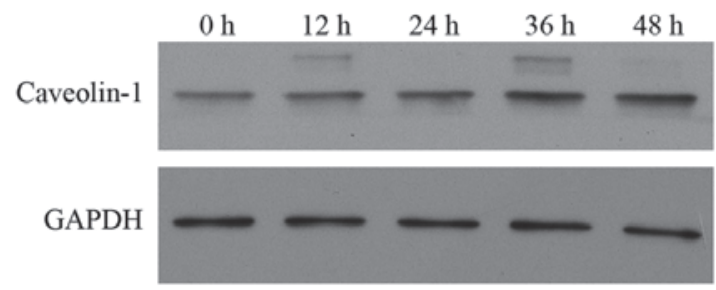

B

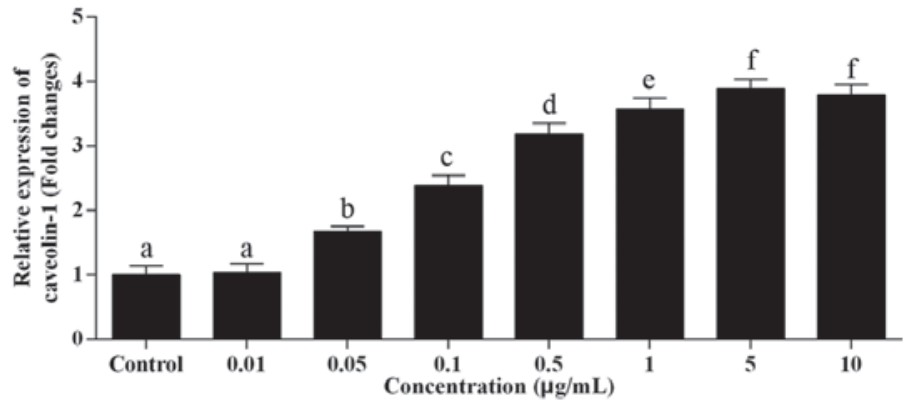

D

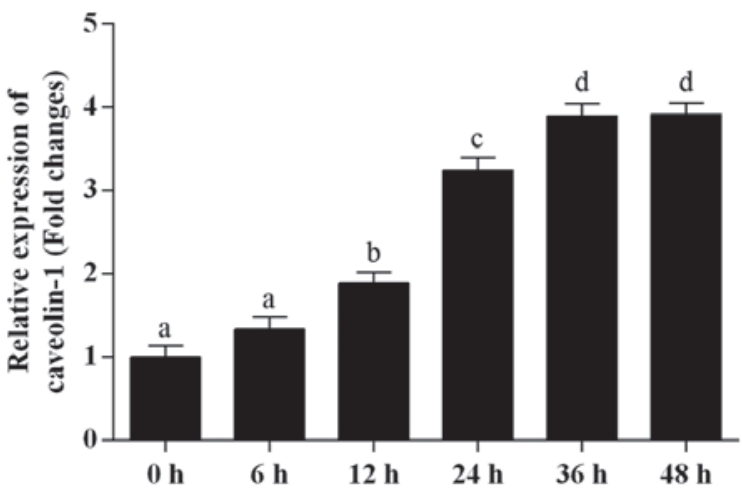

Figure 2. Exposure to leptin enhances the expression of caeolin-1. Following treatment with leptin at concentrations between $0.01 \mathrm{and} 10 \mathrm{mg} / \mathrm{ml}$ for $24 \mathrm{~h}$, the expression levels of caveolin-1 in the cells were measured using (A) western blot analysis and (B) reverse transcription-quantitative polymerase chain reaction analysis. (C) Protein and (D) mRNA expression levels of caveolin-1 were measured in the cells following treatment with leptin $(0.5 \mathrm{mg} / \mathrm{ml})$ for $12,24,36$ and $48 \mathrm{~h}$. Data are presented as the mean \pm standard deviation. Different letters (a-f) represent significant differences between treatment groups ( $\mathrm{P} \leq 0.05)$.
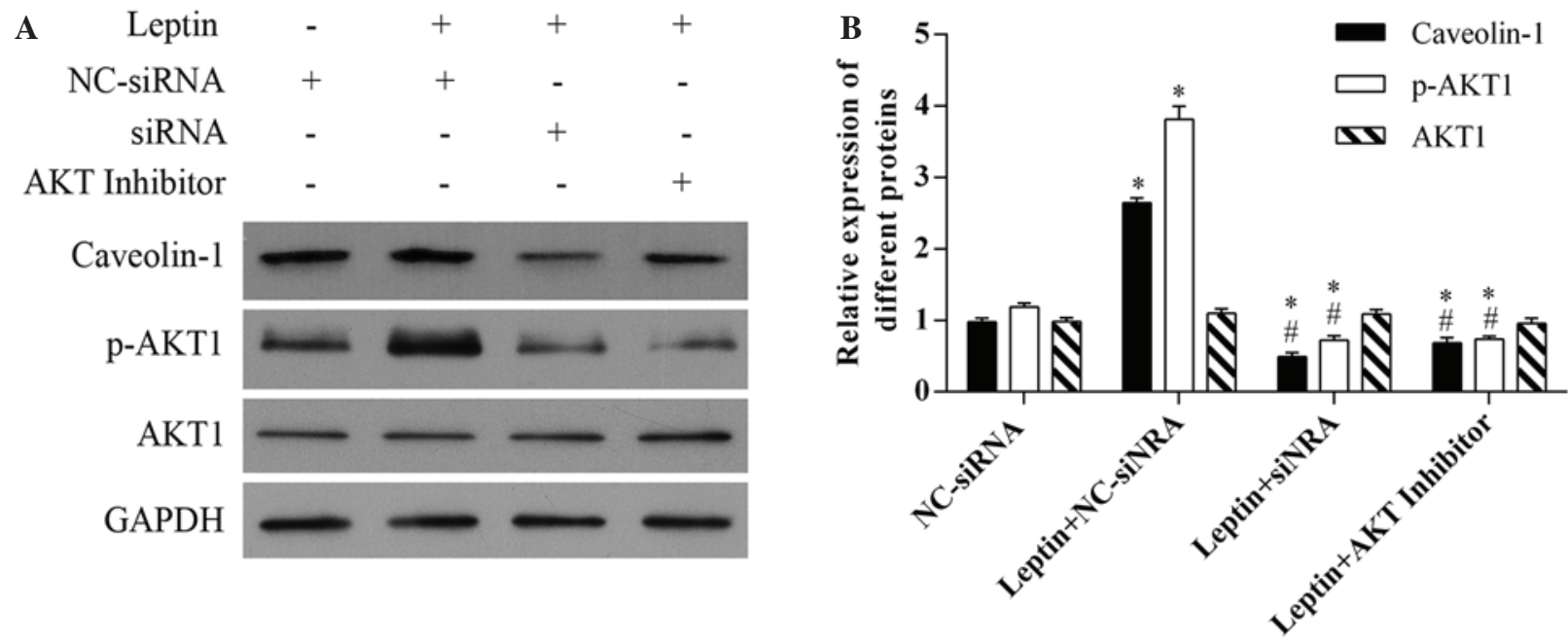

Figure 3. Knockdown of caveolin-1 decreases the activation of Akt by leptin. (A) The effect of caveolin-1 on the activation of Akt by leptin was determined using western blot analysis following caveolin-1 knockdown. (B) Quantification of caveolin 1, pATK and AKT protein expression levels. "P $<0.05$ vs. the NC-siRNA group. ${ }^{\#} \mathrm{P}<0.05$ vs. the Leptin+NC-siRNA group. siRNA, small interfering RNA; NC, negative control; p-, phosphorylated.

using flow cytometry. As shown in Fig. 5, exposure of the cells to leptin at $0.5 \mu \mathrm{g} / \mathrm{ml}$ for $24 \mathrm{~h}$ significantly decreased the proportion of cells in the G0/G1 phase and increased the proportion of cells in the $\mathrm{S}$ phase, compared with the control group, indicating that leptin promoted the cell cycle towards the $\mathrm{S}$ phase. Compared with the decreased proportion of cells in the G01/G1 phase and increased proportion of cells in the $\mathrm{S}$ phase in the cells treated with leptin, caveolin-1 knockdown and the inhibition of Akt activation significantly increased the proportion of cells in the G0/G1 phase and decreased the proportion of cells in the S phase, compared with control group. Furthermore, the proportions of cells in the G0/G1 and $\mathrm{S}$ phases following Akt inhibition were significantly higher and lower, respectively, compared with those following cavelin-1 knockdown. These results revealed that caveolin-1 knockdown and the inhibition of Akt activation arrested hFOB 1.19 cell proliferation via inducing cell cycle arrest at the G0/G1 phase.

Effect of caveolin-1 knockdown and Akt activation inhibition on the apoptosis of cells exposed to leptin. To evaluate whether 


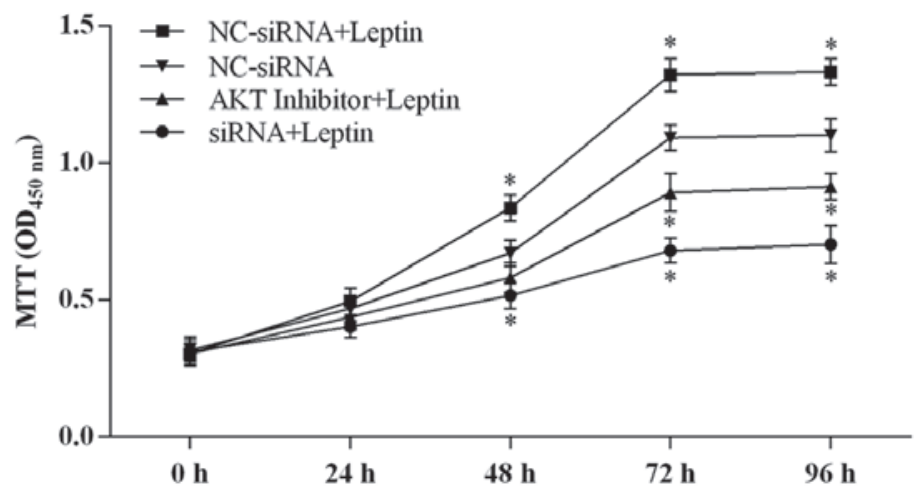

Figure 4. Knockdown of caveolin-1 and inhibition of Akt activation reverses the proliferation effect of leptin. The roles of caveolin-1 and p-Akt in the proliferative effect of leptin were determined using an MTT assay following exposure to leptin for 24, 48, 72 and $96 \mathrm{~h}$. Data are presented as the mean \pm standard deviation. "P $\leq 0.05$, compared with the control group at the same time point. OD, optical density; siRNA, small interfering RNA; NC, negative control.

A
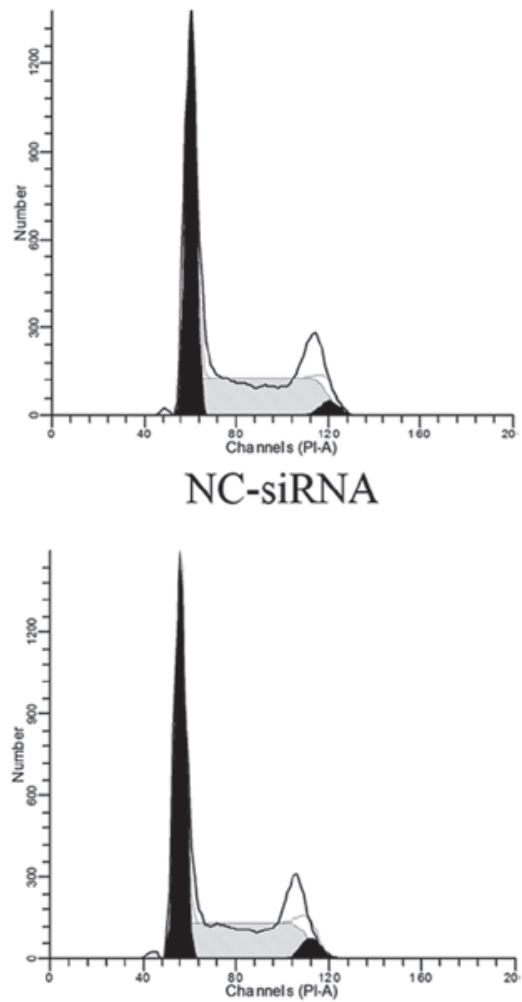

siRNA+Leptin

B

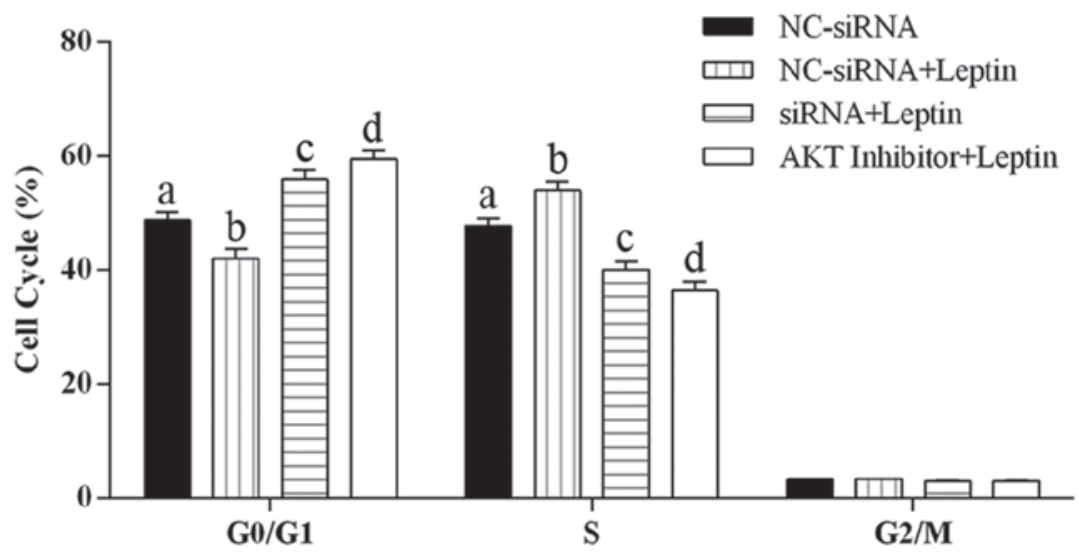

Figure 5. Cell cycle distribution of hFOB 1.19 cells, analyzed using flow cytometry. (A) Cell cycle distribution of hFOB 1.19 cells in the indicated groups following treatment for $48 \mathrm{~h}$. (B) Results of flow cytometry data, based on the cell cycle phase for the indicated groups. Data are presented as the mean \pm standard deviation Different letters (a-d) indicate significant differences between treatment groups ( $\mathrm{P} \leq 0.05)$. siRNA, small interfering RNA; NC, negative control. 
A

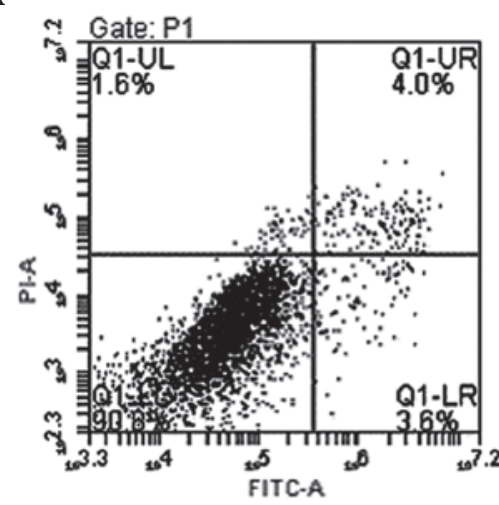

NC-siRNA

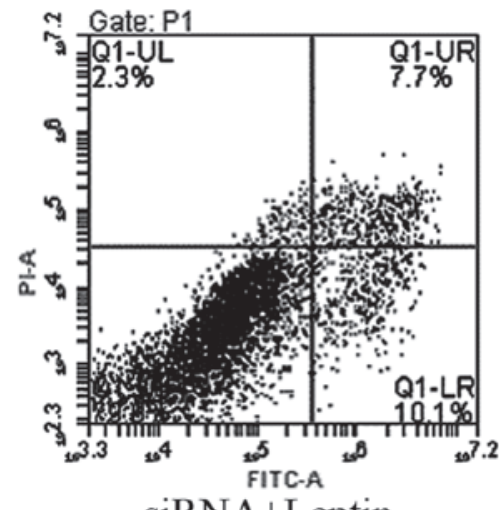

siRNA+Leptin

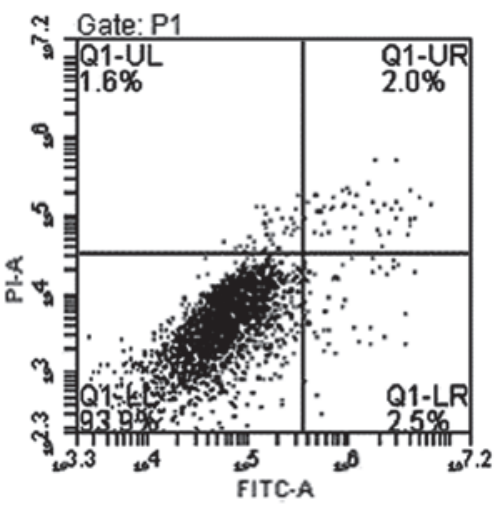

NC-siRNA+Leptin

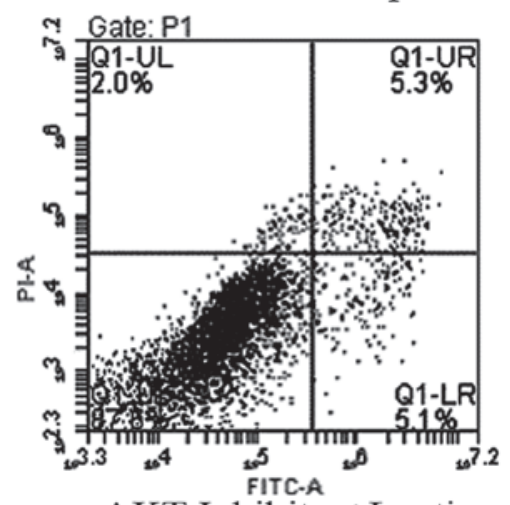

AKT Inhibitor+Leptin

B

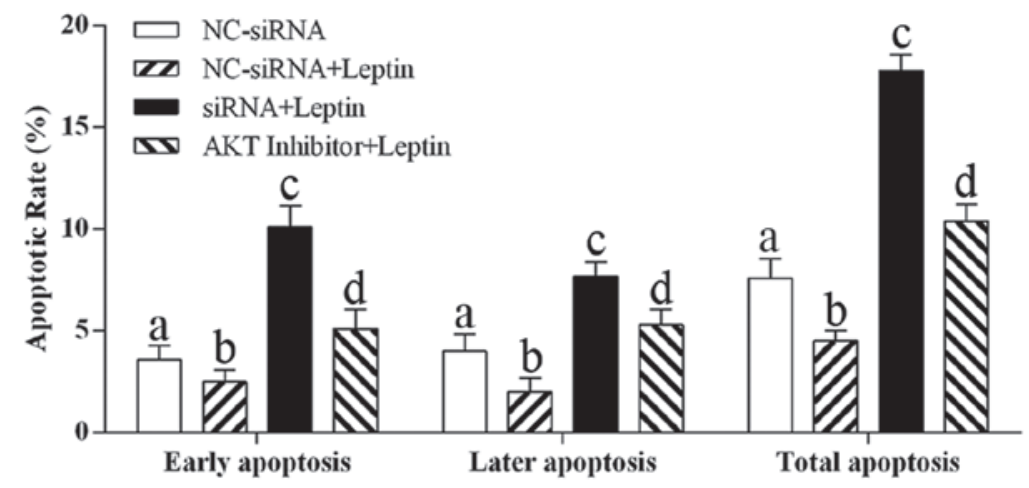

Figure 6. Knockdown of caveolin-1 and inhibition of Akt activation reverses the anti-apoptotic effect of leptin. (A) Dot plots of hFOB 1.19 cells exposed to NC-siRNA, leptin+NC-siRNA, leptin+siNRA or leptin+Akt inhibitor IV for $72 \mathrm{~h}$. (B) Results of flow cytometry data based on the apoptotic rates of the indicated groups. Data are presented as the mean \pm standard deviation Different letters (a-d) indicate significant differences between treatment groups (P $\leq 0.05)$ siRNA, small interfering RNA; NC, negative control; p-, phosphorylated; FITC, fluorescein isothiocyanate; PI, propidium iodide.

caveolin-1 knockdown and Akt inhibition induced cell apoptosis following treatment with $0.5 \mu \mathrm{g} / \mathrm{ml}$ leptin, the rates of apoptosis at the early and late stages were detected. As shown in Fig. 6, treatment with letpin marginally, but significantly, decreased the rate of cell apoptosis at each stage, compared with the control group. By contrast, caveolin-1 knockdown and Akt inhibition resulted in A higher apoptotic rate, compared with th econtrol group. These results revealed that caveolin-1 and p-Akt were critical in the anti-apoptotic effect of leptin on the cells.

\section{Discussion}

It is evident that leptin is important in bone formation (15), however, it remains controversial whether the effects of leptin on bone formation are positive or negative. Osteoblasts, or bone-forming cells, are one of three distinct cell types in bone . It is well known that osteoblasts are positively associated with bone mass and bone density (27). In the present study, it was confirmed that leptin directly enhanced the proliferation of osteoblasts and revealed that this effect was critically mediated by caveolin-1 through the activation of Akt.

Leptin functions as a growth factor in a variety of cell types, including human prostate cancer cells and mouse tracheal epithelial cells $(28,29)$. Gordeladze et al (30) showed that leptin promotes human osteoblast proliferation. Consistently, it was observed that leptin increased the proliferation of the hFOB 1.19 cells in the present study. Additionally, the results of the present study showed that 
leptin suppressed the apoptosis of hFOB 1.19 cells. This supported the results of a previous report, which found that leptin can protect osteoblasts against apoptosis throughout the entire incubation period via enhancing the expression of B cell lymphoma-2 (Bcl-2)-associated X protein- $\alpha$ and $\mathrm{Bcl}-2$ (30). Leptin receptors are present in osteoblasts $(4,31)$, indicating that leptin exerts a proliferative effect on hFOB 1.19 cells by directly binding to its receptor. This further supports the hypothesis that peripheral leptin may protect against bone loss.

As the major structural protein in caveolae, caveolin-1 can be regulated by various cytokines, and is considered to functionally contribute to certain intracellular signaling pathways (32). According to the results of the present study, the expression of caveolin-1 was markedly elevated by leptin. This is consistent with the results of a previous study, which demonstrated that leptin increases the protein expression of caveolin-1 in vascular endothelial cells (33). In the present study, it was demonstrated that caveolin-1 and p-Akt were critical in the proliferative effect of leptin. Furthermore, it was observed that, in the cells with caveolin-1 knockdown, the activation of Akt by leptin was significantly decreased, however, it was significantly higher than that in the control group (Fig. 3), suggesting that caveolin-1 enhanced the activation of Akt by leptin. Taken together, these results indicated that caveolin-1 may be a positive regulator for the proliferative signaling mechanism of leptin. However, this differed from the results of a previous study, which reported that caveolin-1 shares a functional similarity to the suppressor of cytokine signalling proteins, which are involved in the classical negative feedback signaling mechanism (34). Additionally, it has been shown that increased expression of caveolin-1 impairs the activation of extracellular signal-regulated kinase (ERK) induced by exposure to $100 \mathrm{ng} / \mathrm{ml}$ leptin for 0-30 $\mathrm{min}$ in vascular endothelial cells, and may have implications for the development of leptin resistance in the endothelium (33). Caveolin-1 is found to be expressed at high levels in osteoblasts (16). In caveolin-1, there is a scaffolding domain, which can interact with various signal transduction molecules, including src family tyrosine kinases, receptor tyrosine kinases and protein kinase C (35). Zeidan et al (17) demonstrated that caveolin-1 colocalizes with leptin receptors, and suggested that caveolae are important, and may have a primary role in leptin-induced activation of ERK1/2 in vascular smooth muscle cells. This difference between the positive role of leptin in the present study and the negative role in the above mentioned studies may be due to different treatment methods and cell lines.

The present study confirmed the proliferative role of leptin in osteoblasts and demonstrated that caveolin-1 was critical in leptin-induced osteoblast proliferation. However, the present study involved in vitro experiments. Further investigations are required to further elucidate the mechanism of leptin signaling in osteoblasts. These data may assist in the development of therapeutics for leptin-induced bone diseases.

\section{References}

1. Sinha MK, Sturis J, Ohannesian J, Magosin S, Stephens T, Heiman ML, Polonsky KS and Caro JF: Ultradian oscillations of leptin secretion in humans. Biochem Biophys Res Commun 228: $733-738,1996$
2. Maffei M, Halaas J, Ravussin E, Pratley RE, Lee GH, Zhang Y, Fei H, Kim S, Lallone R, Ranganathan S, et al: Leptin levels in human and rodent: Measurement of plasma leptin and ob RNA in obese and weight-reduced subjects. Nat Med 1: 1155-1161, 1995.

3. Zhang $\mathbf{J}$ and Wang $\mathrm{N}$ : Leptin in chronic kidney disease: A link between hematopoiesis, bone metabolism, and nutrition. Int Urol Nephrol 46: 1169-1174, 2014.

4. Reseland JE, Syversen U, Bakke I, Qvigstad G, Eide LG, Hjertner O, Gordeladze JO and Drevon CA: Leptin is expressed in and secreted from primary cultures of human osteoblasts and promotes bone mineralization. J Bone Miner Res 16: 1426-1433, 2001.

5. Taichman RS and Hauschka PV: Effects of interleukin-1 beta and tumor necrosis factor-alpha on osteoblastic expression of osteocalcin and mineralized extracellular matrix in vitro. Inflammation 16: 587-601, 1992.

6. Laharrague P, Larrouy D, Fontanilles AM, Truel N, Campfield A, Tenenbaum R, Galitzky J, Corberand JX, Pénicaud L and Casteilla L: High expression of leptin by human bone marrow adipocytes in primary culture. FASEB J 12: 747-752, 1998.

7. Zhang Y, Proenca R, Maffei M, Barone M, Leopold L and Friedman JM: Positional cloning of the mouse obese gene and its human homologue. Nature 372: 425-432, 1994.

8. Sebastién-Ochoa A, Fernández-Garcia D, Reyes-García R, Mezquita-Raya P, Rozas-Moreno P, Alonso-Garcia G and Muñoz-Torres M: Adiponectin and leptin serum levels in osteoporotic postmenopausal women treated with raloxifene or alendronate. Menopause 19: 172-177, 2012.

9. Lajeunesse D, Pelletier JP and Martel-Pelletier J: Osteoarthritis: A metabolic disease induced by local abnormal leptin activity? Curr Rheumatol Rep 7: 79-81, 2005.

10. Lee SW, Park MC, Park YB and Lee SK: Measurement of the serum leptin level could assist disease activity monitoring in rheumatoid arthritis. Rheumatol Int 27: 537-540, 2007.

11. Wu YP, Chen WS, Xu SJ and Zhang N: Osteoporosis as a potential contributor to the bone metastases. Med Hypotheses 75: 514-516, 2010.

12. Ducy P, Amling M, Takeda S, Priemel M, Schilling AF, Beil FT, Shen J, Vinson C, Rueger JM and Karsenty G: Leptin inhibits bone formation through a hypothalamic relay: A central control of bone mass. Cell 100: 197-207, 2000.

13. Bartell SM, Rayalam S, Ambati S, Gaddam DR, Hartzell DL, Hamrick M, She JX, Della-Fera MA and Baile CA: Central (ICV) leptin injection increases bone formation, bone mineral density, muscle mass, serum IGF-1, and the expression of osteogenic genes in leptin-deficient ob/ob mice. J Bone Miner Res 26: 1710-1720, 2011

14. Neve A, Corrado A and Cantatore FP: Osteoblast physiology in normal and pathological conditions. Cell Tissue Res 343: 289-302, 2011.

15. Takeda S, Elefteriou F, Levasseur R, Liu X, Zhao L, Parker KL, Armstrong D, Ducy P and Karsenty G: Leptin regulates bone formation via the sympathetic nervous system. Cell 111:305-17, 2002.

16. Sawada N, Taketani Y, Amizuka N, Ichikawa M, Ogawa C, Nomoto K, Nashiki K, Sato T, Arai H, Isshiki M, et al: Caveolin-1 in extracellular matrix vesicles secreted from osteoblasts. Bone 41: 52-58, 2007.

17. Zeidan A, Purdham DM, Rajapurohitam V, Javadov S, Chakrabarti S and Karmazyn M: Leptin induces vascular smooth muscle cell hypertrophy through angiotensin II- and endothelin-1-dependent mechanisms and mediates stretch-induced hypertrophy. J Pharmacol Exp Ther 315: 1075-1084, 2005

18. Baker N, Zhang G, You Y and Tuan RS: Caveolin-1 regulates proliferation and osteogenic differentiation of human mesenchymal stem cells. J Cell Biochem 113: 3773-3787, 2012.

19. Solomon KR, Danciu TE, Adolphson LD, Hecht LE and Hauschka PV: Caveolin-enriched membrane signaling complexes in human and murine osteoblasts. J Bone Miner Res 15: 2380-2390, 2000.

20. Hens JR, Wilson KM, Dann P, Chen X, Horowitz MC, Wysolmerski JJ: TOPGAL mice show that the canonical Wnt signaling pathway is active during bone development and growth and is activated by mechanical loading in vitro. $\mathrm{J}$ Bone Miner Res 20: 1103-1113, 2005.

21. Forbes A, Wadehra M, Mareninov S, Morales S, Shimazaki K, Gordon LK and Braun J: The tetraspan protein EMP2 regulates expression of caveolin-1. J Biol Chem 282: 26542-26551, 2007. 
22. Basu Roy UK, Henkhaus RS, Loupakis F, Cremolini C, Gerner EW and Ignatenko NA: Caveolin-1 is a novel regulator of K-RAS-dependent migration in colon carcinogenesis. Int J Cancer 133: 43-57, 2013.

23. Livak KJ and Schmittgen TD: Analysis of relative gene expression data using real-timequantitative PCR and the 2(-Delta Delta C(T)) Method. Methods 25: 402-408, 2001.

24. Liu GY, Liang QH, Cui RR, Liu Y, Wu SS, Shan PF, Yuan LQ and Liao EY: Leptin promotes the osteoblastic differentiation of vascular smooth muscle cells from female mice by increasing RANKL expression. Endocrinology 155: 558-567, 2014.

25. Li Z, Shen J, Wu WK, Yu X, Liang J, Qiu G and Liu J: Leptin induces cyclin D1 expression and proliferation of human nucleus pulposus cells via JAK/STAT, PI3K/Akt and MEK/ERK pathways. PLoS One 7: e53176, 2012.

26. Beaulieu A, Poncin G, Belaid-Choucair Z, Humblet C, Bogdanovic G, Lognay G, Boniver J and Defresne MP: Leptin reverts pro-apoptotic and antiproliferative effects of $\alpha$-linolenic acids in BCR-ABL positive leukemic cells: Involvement of PI3K pathway. PLoS One 6: e25651, 2011.

27. Lloyd JT, Alley DE, Hawkes WG, Hochberg MC, Waldstein SR and Orwig DL: Body mass index is positively associated with bone mineral density in US older adults. Arch Osteoporos 9: 175, 2014.

28. Frankenberry KA, Somasundar P, McFadden DW and Vona-Davis LC: Leptin induces cell migration and the expression of growth factors in human prostate cancer cells. Am J Surg 188: $560-565,2004$.
29. Tsuchiya T, Shimizu H, Horie T and Mori M: Expression of leptin receptor in lung: Leptin as a growth factor. Eur J Pharmacol 365: 273-279, 1999.

30. Gordeladze JO, Drevon CA, Syversen U and Reseland JE: Leptin stimulates human osteoblastic cell proliferation, de novo collagen synthesis, and mineralization: Impact on differentiation markers, apoptosis, and osteoclastic signaling. J Cell Biochem 85: 825-836, 2002

31. Lee YJ, Park JH, Ju SK, You KH, Ko JS and Kim HM: Leptin receptor isoform expression in rat osteoblasts and their functional analysis. FEBS Lett 528: 43-47, 2002.

32. Zhang J, Lazarenko OP, Blackburn ML, Badger TM, Ronis MJ and Chen JR: Soy protein isolate down-regulates caveolin-1 expression to suppress osteoblastic cell senescence pathways. FASEB J 28: 3134-3145, 2014.

33. Singh P, Peterson TE, Sert-Kuniyoshi FH, Jensen MD and Somers VK: Leptin upregulates caveolin-1 expression: Implications for development of atherosclerosis. Atherosclerosis 217: 499-502, 2011.

34. Jasmin JF, Mercier I, Sotgia F and Lisanti MP: SOCS proteins and caveolin-1 as negative regulators of endocrine signaling. Trends Endocrinol Metab 17: 150-158, 2006.

35. Razani B, Woodman SE and Lisanti MP: Caveolae: From cell biology to animal physiology. Pharmacol Rev 54: 431-467, 2002 . 